\title{
P-199 前立腺肥大症に対する経尿道バルーンレーザーサーミアの治癔成績
}

\section{高㚘病院}

古倉浩次、須藤孝治、吉田隆夫

【目的】前立腺肥大症患者に経尿道レーザーバルーンを用いた前立腺高温度治療（PROSTA LASE)を経験したので治療効果について検討した。

【対象】1994年3月より、高柣病院においてプロスタレーズを施行した前立腺肥大患者32例

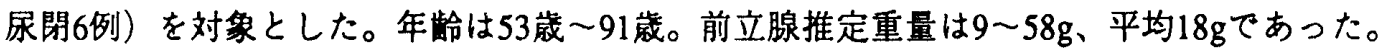
【方法】Nd：YAGレーザー（ＳＬＴシャパン社製）と温度制御システムを用い、尿道粘膜麻 酔下にレーザーバルーンカテーテルを尿道に留直し、直腸温モニター下に前立腺部尿道にレーザ 一照射を行った。20Wから50Wのレーザーを直腸温が40度を越えた時から断続的に40分間照射し た。尿道粘膜は冷却水を灌流し保讙した。効果判定は治療前後のA U A スコア、尿流量测定、前 立腺重量、残尿量によりおこなった。

【結果】尿閉患者6名はすべて自尿可能となった。尿䦥患者および追跡不能例等を除いた 21 例 の治療後 1 力月および 3 カ月の評価では平均尿流量、最大尿流量は治療前平均士 S D (ml/s) 3.5

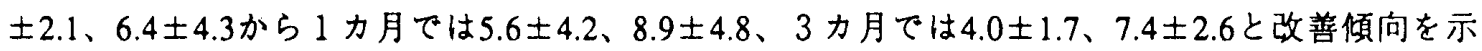

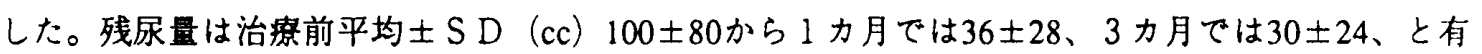
意な改善を認めた。A U A スコアは治療前20、1 カ月11、3 カ月9と有意な改善を認めた。前立 腺重量に関しては縮小傾向はあるものの有意差はなかった。

【結語】本治潦法は患者への負担が軽く、安全かつ効果的であると考えられた。発表時までに 症例を增やし、治療後 6 力月での評価についても報告する予定である。

\section{P-200 プロスタスコープを使用した程尿道的レーザー前立媳治旗}

\author{
久留米大”、大有田市立 ${ }^{2)}$

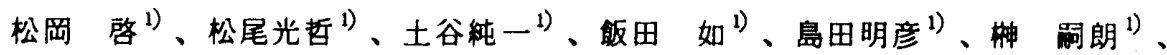 \\ 菊池英雄 ${ }^{1)}$ 、小田倉隆 ${ }^{1)}$ 、中並正之 ${ }^{1)}$ 、野田進士 ${ }^{1)}$ 、末金茂高 ${ }^{2)}$ 、大像裕司 ${ }^{2)}$
}

【目的】経尿道的レーザー前立腺治療们いて、スタンダードファイバーが使用できるプロスタスコープの有用 性について検討した。【対象と方法】前立腺肥大症患者25例（平均年齢69藏）について、レーサーリフレクター を有するプロスタスコープを使用して内視鏡的Nd：YAGレーザー前立腺治獜を行った。使用したレーザー発生 装䈯は主に P E N T A X S L Y-1で出力は 60 Wである。治庰開始当初は原則として2、4、8、10時におい て膀胱頸部より精皁までクレイターが形成されるまで線状化照射したが、最近ではクレイター形成部も含めなる

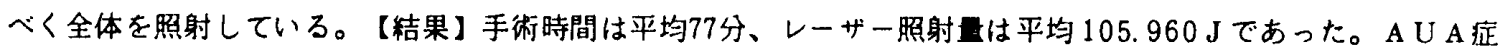
状スコアは、術前2 1 が 1 力月後 $7.5 、 3$ 力月後 $6 、 6$ 力月後 2 と、いずれも有意化改善した。最大良流量率は、 術前 $9.6 \mathrm{~m} \mathrm{l} / \mathrm{s}$ 力 1 力月後 $11.5 \mathrm{ml} / \mathrm{s} 、 3$ 力月後 $17.1 \mathrm{ml} / \mathrm{s} 、 6$ 力月後 $13.2 \mathrm{ml} / \mathrm{s}$ と、3 力月目化有意汇改善 した。残尿量は術前 $60 \mathrm{ml}$ が 1 力月後 $30 \mathrm{ml} 、 3$ 力月後 $12 \mathrm{ml} 、 6$ 力月後 $33 \mathrm{ml}$ と3力月のみで有意汇隇少した。 術後Foleyカテーテルの留置期間は平均11日であった。またカテーテル抜去後の一過性尿閉例は７例であった。 【考察】側射型レーザーファイバーの出現により、経尿道的レーザー前立腺治療は有効な治療手段となりつつあ ろが、側射型ファイバーは原則として単回使用で高価であるので経済性に問題がある。今回使用したプロスタス コープは安価でスタンダードファイバーが使用可能、しかもレーザーリフレクター部は頻回の使用が可能という 利点を有する。本器を使用して期待した治療效果が得られたが、手術時間やカテーテル留置期間、カテ抜去後の 尿閉出現などの問題点も明らかになったので症例を重るて解決してゆきたい。【結論】プロスタスコープを使用 した経尿道的レーザー前立腺治港は経消的で、将来有用な治療法になり得ると考えている。 